\title{
Assessment of the protective effectiveness of a volatile inhibitor in atmospheric corrosion of steel under conditions of increased concentrations of carbon dioxide, ammonia and hydrogen sulfide by electrochemical methods
}

\author{
V.I. Vigdorovich ${ }^{+1}{ }^{1}$ L.E. Tsygankova, ${ }^{2 *}$ N.V. Shel, ${ }^{3}$ L.G. Knyazeva, ${ }^{1}$ \\ A.V. Dorokhov ${ }^{1}$ and A.A. Uryadnikov ${ }^{2}$ \\ ${ }^{1}$ All-Russian Scientific Research Institute of Use of Machinery and Oil Products, Novo- \\ Rubezhnyi per., 28, Tambov, 392022, Russian Federation \\ ${ }^{2}$ Derzhavin State University, ul. Internatsyonalnaya, 33, Tambov, 392000, Russian \\ Federation \\ ${ }^{3}$ Tambov State Technical University, ul. Sovetskaya, 106, Tambov, 392000, Russian \\ Federation \\ *E-mail: vits21@mail.ru
}

\begin{abstract}
The effect of the combined presence of atmospheric corrosion stimulants $\mathrm{NH}_{3}$ and $\mathrm{CO}_{2}$ was modeled by introducing $\left(\mathrm{NH}_{4}\right)_{2} \mathrm{CO}_{3}$ salt into the solution. And the presence of $\mathrm{NH}_{3}$ and $\mathrm{H}_{2} \mathrm{~S}$ was modeled by introducing the corresponding amounts of $\mathrm{NH}_{4} \mathrm{OH}$ and $\mathrm{H}_{2} \mathrm{~S}$ into the solution. The presence of these corrosion stimulants in the air is characteristic for livestock buildings. The influence of the concentration of $\left(\mathrm{NH}_{4}\right)_{2} \mathrm{CO}_{3}$ and $\left(\mathrm{NH}_{4}\right)_{2} \mathrm{~S}$ salts $(10-500 \mathrm{mg} / \mathrm{L})$ and the IFKHAN-114 volatile inhibitor $(100 \mathrm{mg} / \mathrm{L})$ during the corrosion of St3 steel in a $0.1 \mathrm{M} \mathrm{NaCl}$ solution was studied using methods of potentiodynamic polarization and spectroscopy of electrochemical impedance. Potentiodynamic measurements at a potential sweep rate of $0.66 \mathrm{mV} / \mathrm{s}$ were carried out in a three-electrode electrochemical cell made of Pyrex glass with a platinum auxiliary electrode and silver-silver chloride reference electrode using an IPC-Pro MF potentiostat. It was shown that in the absence of IFKHAN-114, the products of the hydrolysis of both salts as a result of their almost complete conversion to ammonium hydroxide and the corresponding weak acids cause intensive inhibition of corrosion of St3 carbon steel in $0.1 \mathrm{M} \mathrm{NaCl}$ solution. The protective effect reaches $90-96 \%$. Introduction of IFKHAN-114 $(100 \mathrm{mg} / \mathrm{L})$ at low concentrations of $\left(\mathrm{NH}_{4}\right)_{2} \mathrm{CO}_{3}(10 \mathrm{mg} / \mathrm{L})$ has a stimulating effect on St3 steel, but starting with $20 \mathrm{mg} / \mathrm{L}$ of the salt this effect is replaced by an inhibitory one. Its value increases with increasing salt concentration, reaching $67 \%$ with a formal content of $100 \mathrm{mg} / \mathrm{L}$ ammonium carbonate in the solution. In the presence of ammonium sulfide, the protective effect is maximum at a low salt content $(10 \mathrm{mg} / \mathrm{L})$ and significantly decreases with increasing salt concentration, more precisely the products of its complete hydrolysis. The impedance measurements confirm the results obtained by the method of potentiodynamic polarization.
\end{abstract}


Keywords: steel, volatile inhibitor, corrosion, atmosphere, ammonia, hydrogen sulfide, carbon dioxide, polarization, impedance.

Received: August 6, 2018. Published: January 16, 2020

doi: $\underline{10.17675 / 2305-6894-2020-9-1-2}$

\section{Introduction}

In agricultural production, steel equipment is widely used, as well as protection and control systems [1]. The most unfavorable conditions for the operation of such systems are observed in livestock buildings, on numerous commodity farms. They are characterized by high relative humidity $(\sim 100 \%)$, accompanied by an increased concentration of atmospheric corrosion stimulants (CS) of metals: $\mathrm{CO}_{2}, \mathrm{NH}_{3}, \mathrm{H}_{2} \mathrm{~S}$ (relative to the background one) presenting separately and together. This leads to an accelerated failure of electrical equipment, friction pairs, moving contacts, casings, and destruction of insulation. To protect metal surfaces under such conditions, it is advisable and technologically advanced to use volatile corrosion inhibitors (VCI). However, they did not find serious systematic use in agricultural production. At the same time, VCIs are successfully used to protect the most critical units, internal combustion engines, steam boilers during a stop period, and to preserve products with closed internal planes in other industries [2-4].

Previously [5], we have shown the high efficiency of the IFKHAN-118 VCI for suppressing atmospheric corrosion of St3 carbon steel and L62 brass under conditions of $100 \%$ relative air humidity at room temperature.

The purpose of this work is to study the possibility of an electrochemical assessment of the protective effect of the IFKHAN-114 inhibitor during atmospheric corrosion of St3 steel in air containing simultaneously $\mathrm{NH}_{3}$ and $\mathrm{CO}_{2}$ or $\mathrm{NH}_{3}$ and $\mathrm{H}_{2} \mathrm{~S}$.

\section{Experimental}

IFKHAN-114, which is an nonequivalent mixture of polyaniline with benzoic acid, readily soluble in water and sparingly soluble in benzene (TU 24155-114-16424386-2018) with a saturated vapor pressure of less than $0.130 \mathrm{~Pa}$ (third hazard class), was used as VCI. Potentiodynamic measurements at a potential sweep rate of $0.66 \mathrm{mV} / \mathrm{s}$ were carried out in a three-electrode electrochemical cell made of Pyrex glass with a platinum auxiliary electrode and silver-silver chloride reference electrode using an IPC-Pro MF potentiostat (produced at the Institute of Physical Chemistry and Electrochemistry, Russian Academy of Sciences) in $0.1 \mathrm{M} \mathrm{NaCl}$ solution containing inhibitor and the corresponding salts simulating the presence of CSs in atmospheric air. Electrochemical impedance spectroscopy measurements (Solartron 1250 FRA) were carried out in a frequency range of $10 \mathrm{kHz}-50 \mathrm{mHz}$ in the solutions under study at the corrosion potential [6].

Electrodes made of steel St3 with a chemical composition (\% (wt.): $0.28 \mathrm{C} ; 0.70 \mathrm{Mn}$; $0.15 \mathrm{Si} ; 0.04 \mathrm{P} ; 0.05 \mathrm{~S} ; 0.30 \mathrm{Cr} ; 0.20 \mathrm{Ni}$ and $0.20 \mathrm{Cu}$ with a working surface (WS) of $0.8 \mathrm{~cm}^{2}$ was reinforced with a mandrel made of epoxy resin with hardener polyethylene polyamine. Before the experiment, WSs were polished to a purity class of 6 , washed with 
distilled water, and dried with filter paper. A $0.1 \mathrm{M} \mathrm{NaCl}$ solution was used as the background.

Certain difficulties are associated with modeling the effects of corrosion stimulants $\mathrm{NH}_{3}, \mathrm{CO}_{2}$ and $\mathrm{H}_{2} \mathrm{~S}$, which in a certain way, depending on the nature of the compound, are distributed between the gas and liquid phases. At the same time, it is taken into account that the indicated CSs dissolving in the phase surface film of moisture are almost completely hydrolyzed to form the $\mathrm{NH}_{4} \mathrm{OH}$ base and the corresponding acids $\mathrm{H}_{2} \mathrm{CO}_{3}$ and $\mathrm{H}_{2} \mathrm{~S}$, which must interact with each other to produce $\left(\mathrm{NH}_{4}\right)_{2} \mathrm{CO}_{3}$ and $\left(\mathrm{NH}_{4}\right)_{2} \mathrm{~S}$ salts:

$$
\begin{aligned}
2 \mathrm{NH}_{3}+\mathrm{H}_{2} \mathrm{CO}_{3} & \rightarrow\left(\mathrm{NH}_{4}\right)_{2} \mathrm{CO}_{3} \\
2 \mathrm{NH}_{3}+\mathrm{H}_{2} \mathrm{~S} & \rightarrow\left(\mathrm{NH}_{4}\right)_{2} \mathrm{~S}
\end{aligned}
$$

But these salts, due to the fact that they are formed by weak base and weak acids, are almost completely hydrolyzed to give the starting products.

Taking into consideration this fact, the effect of the combined presence of $\mathrm{NH}_{3}$ and $\mathrm{CO}_{2}$ was modeled by introducing $\left(\mathrm{NH}_{4}\right)_{2} \mathrm{CO}_{3}$ (qualification of "analytical grade") into the background solution at concentrations of $10,20,50$, and $100 \mathrm{mg} / \mathrm{L}$. With modeling the combined effect of $\mathrm{NH}_{3}$ and $\mathrm{H}_{2} \mathrm{~S}$, the situation is more complicated, since the $\left(\mathrm{NH}_{4}\right)_{2} \mathrm{~S}$ salt cannot be obtained. Therefore, equivalent amounts of $\mathrm{Na}_{2} \mathrm{~S}$ and $\mathrm{NH}_{4} \mathrm{Cl}$ were introduced into the background electrolyte solution (used to achieve the required electrical conductivity) to obtain $\left(\mathrm{NH}_{4}\right)_{2} \mathrm{~S}$ at the concentrations of $10-500 \mathrm{mg} / \mathrm{L}$. This resulted in the hydrolysis of $\mathrm{NH}_{4}^{+}$and $\mathrm{S}^{2-}$ ions to form $\mathrm{NH}_{4} \mathrm{OH}$ and $\mathrm{H}_{2} \mathrm{~S}$, which are stable in the surface phase film, as noted above. To compare the results obtained by electrochemical and weight tests, the latter were carried out in sealed desiccators with a volume of $7 \mathrm{~L}$, where the specified concentration of CSs was created in the gas phase according to the method proposed by the authors of the article [7]. The value of $100 \%$ relative humidity in the desiccators was achieved by the presence in them of an additional small capacity with distilled water. To create the pressure of the saturated vapor of the inhibitor, a glass containing IFKHAN-114 was placed in them. The duration of corrosion tests is 240 hours.

\section{Results and discussion}

The protective effect of the IFKHAN-114 inhibitor (saturation concentration) during corrosion of steel in the atmosphere with 0.2 vol. $\% \mathrm{CO}_{2}$ and $20 \mathrm{mg} / \mathrm{m}^{3} \mathrm{NH}_{3}$ is $76 \%$, in the gas phase - with $10 \mathrm{mg} / \mathrm{m}^{3} \mathrm{H}_{2} \mathrm{~S}$ and $20 \mathrm{mg} / \mathrm{m}^{3} \mathrm{NH}_{3}-70 \%$. The indicated concentrations of $\mathrm{NH}_{3}$ and $\mathrm{H}_{2} \mathrm{~S}$ are the maximum permissible ones for the atmosphere of livestock buildings, the $\mathrm{CO}_{2}$ content in them is not standardized.

Polarization curves characterizing the effect of $10 \mathrm{mg} / \mathrm{L}\left(\mathrm{NH}_{4}\right)_{2} \mathrm{CO}_{3}$ in the absence and presence of $100 \mathrm{mg} / \mathrm{L}$ inhibitor are shown in Figure 1. Note that in the background solution, the corrosion potential of steel decreases by more than $0.100 \mathrm{~V}$ for 24 hours of exposure to the medium. Accordingly, the cathodic reaction is inhibited and the anode process is accelerated. Both of these factors lead to a shift in $E_{\text {cor }}$ to more negative values. 
But to determine which of them has the prevailing effect, in this case is not possible. We point out that as a result of one-day exposure to a corrosive medium, the corrosion rate of steel, expressed in electrical units, decreases from the initial one, equal to $1.1 \mathrm{~A} / \mathrm{m}^{2}$, to $0.37 \mathrm{~A} / \mathrm{m}^{2}$ (see Figure 1, curves 1 and 2).

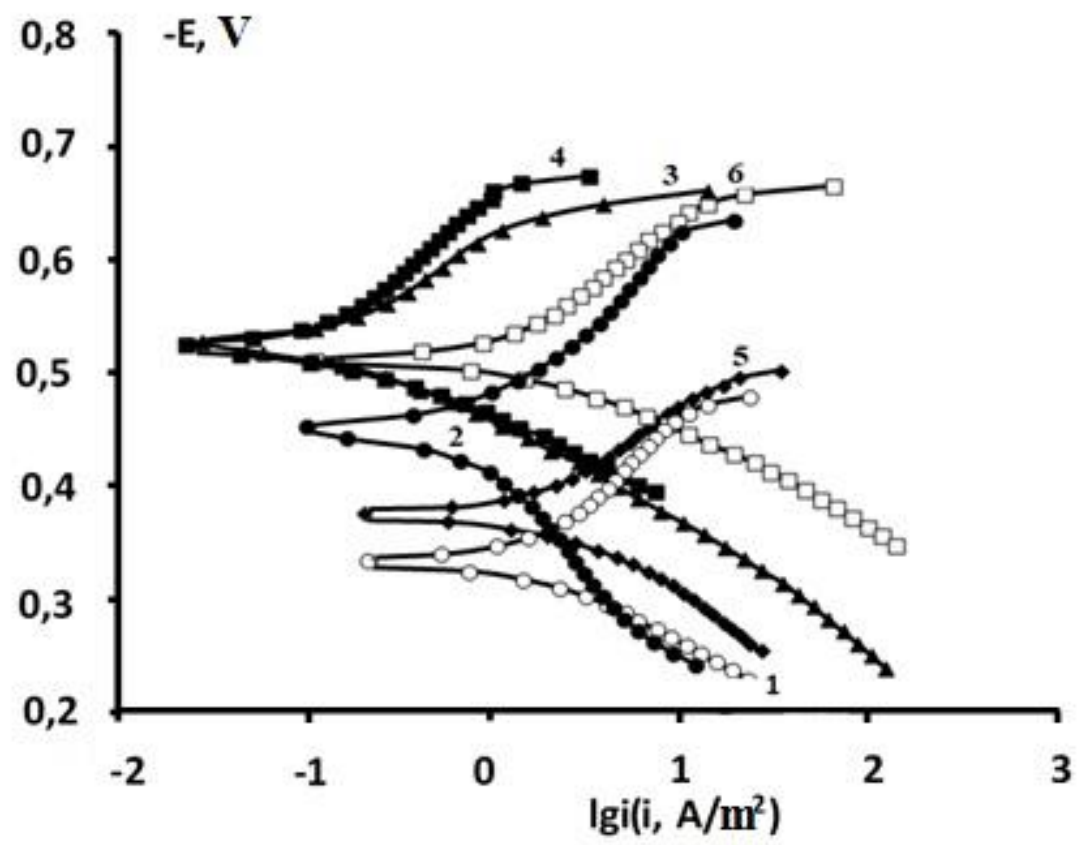

Figure 1. Potentiodynamic polarization curves of $\mathrm{St} 3$ steel in a $0.1 \mathrm{M} \mathrm{NaCl}$ solution immediately after immersion in a corrosive medium $(1,3,5)$ and after a day in it $(2,4,6): 1$ and 2 - no additives; 3, 4 - with additives of $10 \mathrm{mg} / \mathrm{L}\left(\mathrm{NH}_{4}\right)_{2} \mathrm{CO}_{3} ; 5,6$ - with additives of $10 \mathrm{mg} / \mathrm{L}\left(\mathrm{NH}_{4}\right)_{2} \mathrm{CO}_{3}+100 \mathrm{mg} / \mathrm{L}$ IFKHAN-114.

The introduction of $10 \mathrm{mg} / \mathrm{L}$ of ammonium carbonate into the solution with the formation of $\mathrm{NH}_{4} \mathrm{OH}$ and $\mathrm{H}_{2} \mathrm{CO}_{3}$ as a result of almost complete hydrolysis of this salt reduces the corrosion rate of steel to $0.09 \mathrm{~A} / \mathrm{m}^{2}$. Note that, according to weight tests carried out in the gas phase, the presence of $\mathrm{CO}_{2}$ and $\mathrm{NH}_{3}$ together does not reduce the corrosion rate, but increases it. Therefore, inhibition of general corrosion is achieved due to the synergistic effect in the presence of hydrolysis products of ammonium carbonate and chloride ions. This is most likely due to the fact that $\mathrm{Cl}^{-}$-anions are surface-active with respect to iron and carbon steel. In this case, $i_{\text {cor }}$ of $\mathrm{St} 3$ steel immediately after immersion in the solution and after one day exposure remains constant $\left(0.09 \mathrm{~A} / \mathrm{m}^{2}\right)$ (Figure 1, curve 3). Thus, the first portion of sorbates occupying the most active centers has a synergistic effect. $E_{\text {cor }}$ remains constant for 24 hours in a corrosive environment.

The introduction of the IFKHAN-114 inhibitor under these conditions does not slow down, but accelerates the corrosion of steel: immediately after its immersion in the solution, the $i_{\text {cor }}$ increases to $0.91 \mathrm{~A} / \mathrm{m}^{2}$, and the corrosion potential increases due to the sharp relief of the cathodic reaction with a noticeable retardation of the anode process (see Figure 1, curves 3,4,5). Further stay of the steel in a seemingly inhibited medium 
increases $i_{\text {cor }}$ even more, which reaches the value previously observed in the background solution without the addition of the salt and IFKHAN-114. The values of the Tafel slope coefficients of the cathode and anode linear sections of the polarization curves are $0.110 \mathrm{~V}$ and $0.065 \pm 0.005 \mathrm{~V}$, respectively, and are practically independent of the concentration of ammonium carbonate, the presence of an inhibitor, and the duration of exposure to the medium for 24 hours. With an increase in the concentration of ammonium carbonate, the picture changes fundamentally. The corresponding experimental results are given in Table 1.

Table 1. Dependence of the potential and corrosion rate of steel on the concentration of ammonium carbonate and a presence of the inhibitor in the background solution immediately after immersion into a solution $\left(E_{\text {cor.1 }}, i_{\text {cor.1. }}\right)$ and after 24 hours of exposure to the medium $\left(E_{\text {cor.2, }}, i_{\text {cor.2 }}\right)$. ( - the inhibitor is absent; + the inhibitor is present).

\begin{tabular}{ccccccc}
\hline Medium & $\begin{array}{c}\boldsymbol{C}_{\text {salt, }} \\
\mathbf{m g} / \mathbf{L}\end{array}$ & $\begin{array}{c}\text { Presence of } \\
\text { inhibitor }\end{array}$ & $\begin{array}{c}\boldsymbol{E}_{\text {cor.1, }}, \\
\mathbf{V}\end{array}$ & $\begin{array}{c}\boldsymbol{E}_{\text {cor.2, }}, \\
\mathbf{V}\end{array}$ & $\begin{array}{c}\boldsymbol{i}_{\text {cor.1, }}, \\
\mathbf{A} / \mathbf{m}^{\mathbf{2}}\end{array}$ & $\begin{array}{c}\boldsymbol{i}_{\text {cor.2, }} \\
\mathbf{A} / \mathbf{m}^{\mathbf{2}}\end{array}$ \\
\hline 1 & - & - & -0.325 & -0.440 & 1.10 & 0.37 \\
2 & 10 & - & -0.520 & -0.520 & 0.09 & 0.09 \\
3 & 10 & + & -0.360 & -0.500 & 0.91 & 1.10 \\
4 & 20 & - & -0.500 & -0.540 & 0.12 & 0.24 \\
5 & 20 & + & -0.580 & -0.430 & 0.06 & 0.20 \\
6 & 50 & - & -0.480 & -0.500 & 0.36 & 0.23 \\
7 & 50 & + & - & -0.520 & 0.24 & 0.09 \\
8 & 100 & - & -0.465 & -0.515 & 0.14 & 0.06 \\
9 & 100 & + & -0.465 & -0.515 & 0.05 & 0.05 \\
\hline
\end{tabular}

Thus, introduction of $20 \mathrm{mg} / \mathrm{L}\left(\mathrm{NH}_{4}\right)_{2} \mathrm{CO}_{3}$ still significantly reduces $i_{\text {cor. }}$, but this effect is slightly less than that observed at a concentration of $10 \mathrm{mg} / \mathrm{L}$ of salt hydrolysis products. The effect of inhibition of corrosion of steel in the presence of the salt is even weaker after 24 hours of exposure to the environment (Table 1).

In turn, the effect of IFKHAN-114 on the corrosion rate of steel in this case fundamentally changes. The test product does not now stimulate, but inhibits the corrosion process. This conclusion follows from a comparison of the values of $i_{\text {cor.1 }}$ and $i_{\text {cor. } 2}$ in the absence and presence of the inhibitor with $C_{\text {salt }}=$ const.

The values of the protective effect of IFKHAN-114 calculated from the expression:

$$
Z=100\left[\left(i_{\text {cor. } \mathrm{i}}^{0}-i_{\text {cor. } \mathrm{i}}\right) / i_{\text {cor. } \mathrm{i}}^{0}\right],
$$

where $i_{\text {cor.i }}^{0}$ and $i_{\text {cor. }}$ are the corrosion rates of steel at the same moment of exposure to the medium, respectively, in the absence and in the presence of IFKHAN-114, are equal to 
$42 \%$ for the initial moment of corrosion and $17 \%$ after 24 hours of an exposure to the solution. With a further increase in $C_{\text {salt }}$, the values of $Z_{\mathrm{i}}$ increase (Figure 2).

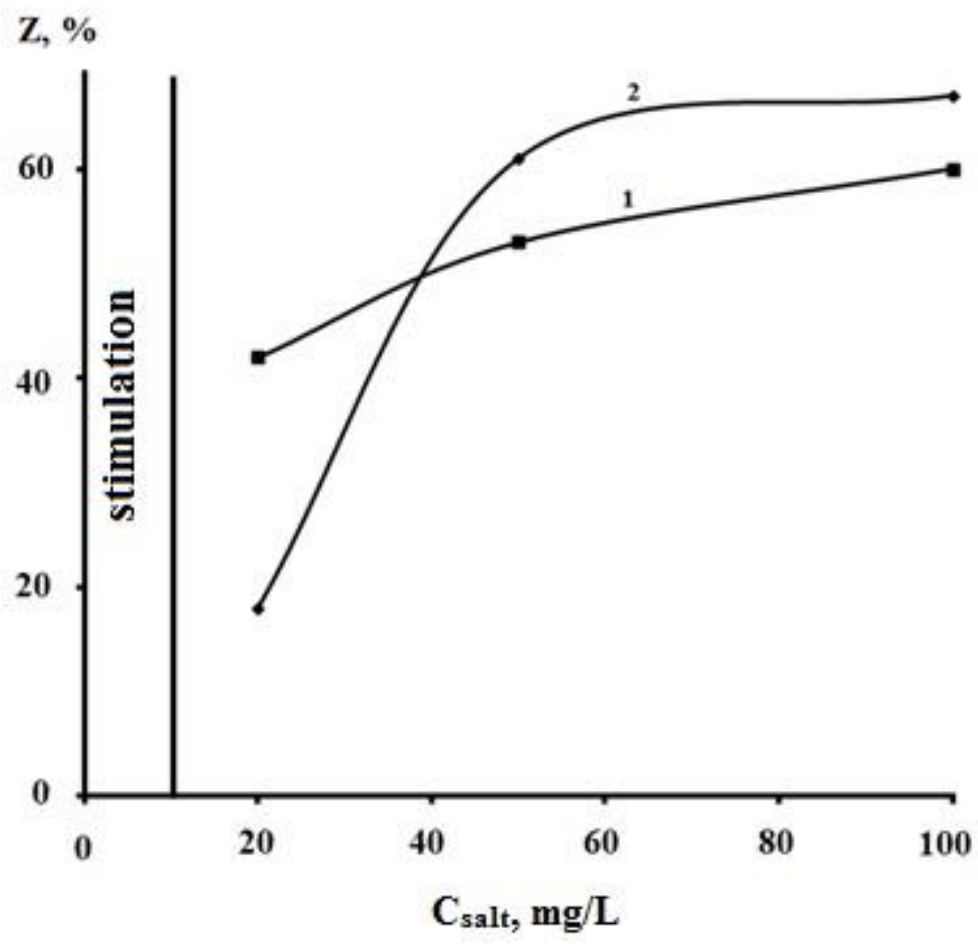

Figure 2. The effect of the concentration of ammonium carbonate on the protective effect of IFKHAN-114 (100 mg/L) during steel corrosion immediately after immersion in the solution (1) and after one-day exposure to the medium (2).

The results obtained suggest that the presence of chloride ions in the solution significantly changes the nature of the effect of the products of hydrolysis of ammonium carbonate on steel corrosion. In their absence, the presence of $\mathrm{NH}_{3}$ and $\mathrm{CO}_{2}$ in the gas phase stimulates the corrosion process; in the presence of $\mathrm{Cl}$ ions, their hydrolysis products act as inhibitory agents. At low initial concentrations of $\left(\mathrm{NH}_{4}\right)_{2} \mathrm{CO}_{3}$ and in the presence of chloride ions, the product IFKHAN-114 acts as a stimulator of corrosion of carbon steel, suppressing the inhibitory effect of the products of hydrolysis of $\left(\mathrm{NH}_{4}\right)_{2} \mathrm{CO}_{3}$. But an increase in the concentration of these products reduces their inhibitory effect, due to which the inhibitory effect of IFKHAN-114 is manifested, which increases as the content of ammonium hydroxide and carbonic acid increases in the solution and their inhibitory effect decreases.

Let us consider the effect of ammonium sulfide as a product that appears in a phase surface moisture film as a result of the interaction of corrosion stimulants $\mathrm{NH}_{3}$ and $\mathrm{H}_{2} \mathrm{~S}$ dissolved in it under atmospheric conditions. The relationship between $E_{\text {cor }}$ of steel and the rate of its total corrosion versus the conditional concentration of ammonium sulfide as a product of the interaction of $\mathrm{NH}_{3}$ and $\mathrm{H}_{2} \mathrm{~S}$ dissolved in a phase film of moisture formed on the steel surface at $100 \%$ relative humidity is shown in the Table 2. 
Table 2. Dependence of the potential and corrosion rate of steel on the seeming concentration of ammonium sulfide and a presence of the inhibitor in the background solution immediately after immersion into a solution $\left(E_{\text {cor.1 }}, i_{\text {cor. } 1}\right)$ and after 24 hours of exposure to the medium $\left(E_{\text {cor.2, }}, i_{\text {cor.2 }}\right)$. ( - the inhibitor is absent; + the inhibitor is present).

\begin{tabular}{ccccccc}
\hline Medium & $\begin{array}{c}\boldsymbol{C} \text { salt, } \\
\mathbf{m g} / \mathbf{L}\end{array}$ & $\begin{array}{c}\text { Presence of } \\
\text { inhibitor }\end{array}$ & $\begin{array}{c}\boldsymbol{E} \text { cor.1, } \\
\mathbf{V}\end{array}$ & $\begin{array}{c}\boldsymbol{E} \text { cor.2, } \\
\mathbf{V}\end{array}$ & $\begin{array}{c}\boldsymbol{i} \text { cor.1, } \\
\mathbf{A} / \mathbf{m}^{2}\end{array}$ & $\begin{array}{c}\boldsymbol{i} \text { cor.2, } \\
\mathbf{A} / \mathbf{m}^{2}\end{array}$ \\
\hline 1 & 10 & - & -0.510 & -0.500 & 0.76 & 0.58 \\
2 & 10 & + & -0.510 & -0.510 & 0.05 & 0.02 \\
3 & 50 & - & -0.470 & -0.500 & 0.26 & 0.22 \\
4 & 50 & + & -0.520 & -0.520 & 0.11 & 0.07 \\
5 & 100 & - & -0.435 & -0.470 & 0.10 & 0.09 \\
6 & 100 & + & - & -0.465 & 0.05 & 0.03 \\
7 & 500 & - & -0.470 & -0.470 & 0.10 & 0.10 \\
8 & 500 & + & -0.480 & -0.400 & 0.07 & 0.05 \\
\hline
\end{tabular}

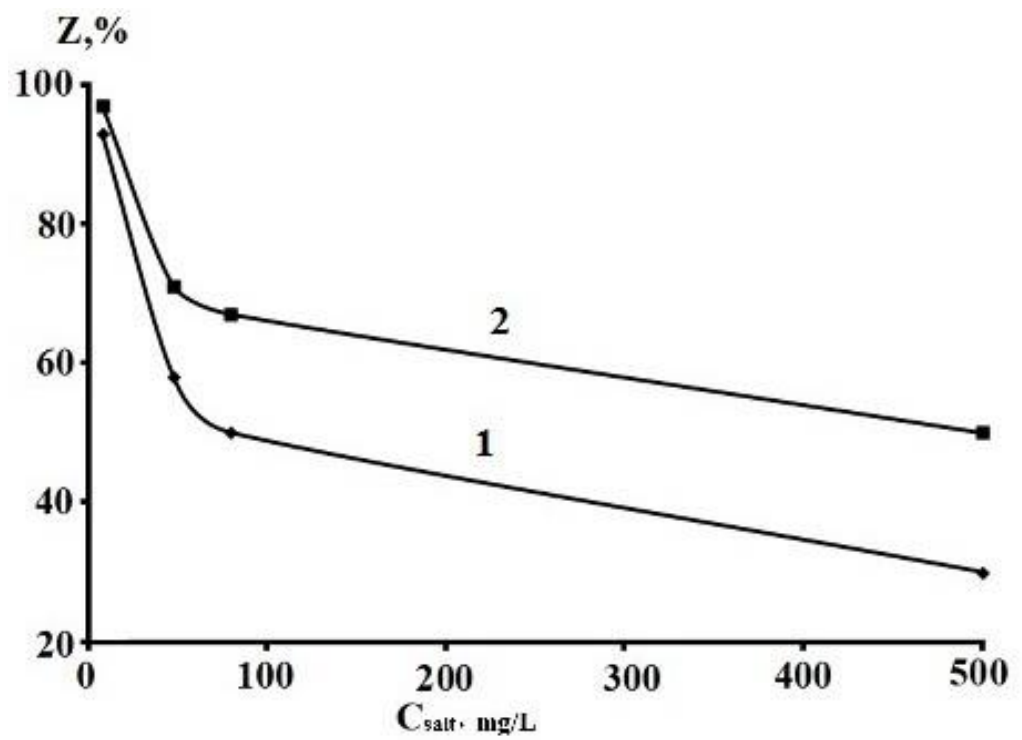

Figure 3. The effect of the apparent concentration of ammonium sulfide on the protective effect of IFKHAN-114 (100 mg/L) during steel corrosion immediately after immersion in the solution (1) and after one-day exposure to the medium (2).

In the presence of ammonium sulfide hydrolysis products in an uninhibited solution in terms of $10 \mathrm{mg} / \mathrm{L}$ of salt, the corrosion rate of steel is $0.76 \mathrm{~g} /\left(\mathrm{m}^{2} \mathrm{~h}\right)$ immediately after immersion in the solution and decreases by a factor of 1.3 in a day (in situ). With the simultaneous introduction of $\mathrm{NH}_{3}$ and $\mathrm{H}_{2} \mathrm{~S}$, as well as $100 \mathrm{mg} / \mathrm{L}$ of the IFKHAN-114 product, the concentration of which did not change in all subsequent experiments, the rate of general corrosion of steel decreases at the initial moment 15-fold, and after 24 hours 29 -fold. The inhibitory effect of IFKHAN-114 is also observed at other concentrations of 
ammonium sulfide hydrolysis products. The values of $Z$ calculated by the formula (1) are shown in Figure 3.

The nature of the effect of the concentration of the products of the hydrolysis of ammonium sulfide on the $Z$ value of the inhibitor is significantly different than in the case of $\left(\mathrm{NH}_{4}\right)_{2} \mathrm{CO}_{3}$ (Figures 2 and 3). If an increase in the apparent concentration of $\left(\mathrm{NH}_{4}\right)_{2} \mathrm{~S}$ reduces the efficiency of IFKHAN-114 (Figure 3), then the picture is opposite for $\left(\mathrm{NH}_{4}\right)_{2} \mathrm{CO}_{3}$ (Figure 2). That is why $\left(\mathrm{NH}_{4}\right)_{2} \mathrm{~S}$ does not cause the stimulating effect of this product, and the anionic component of the salt is the determining factor.

The results of impedance measurements on a steel electrode at the corrosion potential after 15 minutes exposure to a $0.1 \mathrm{M} \mathrm{NaCl}$ solution with $\left(\mathrm{NH}_{4}\right)_{2} \mathrm{CO}_{3}$ additives in the absence and presence of IFKHAN-114 are shown in Figure 4.

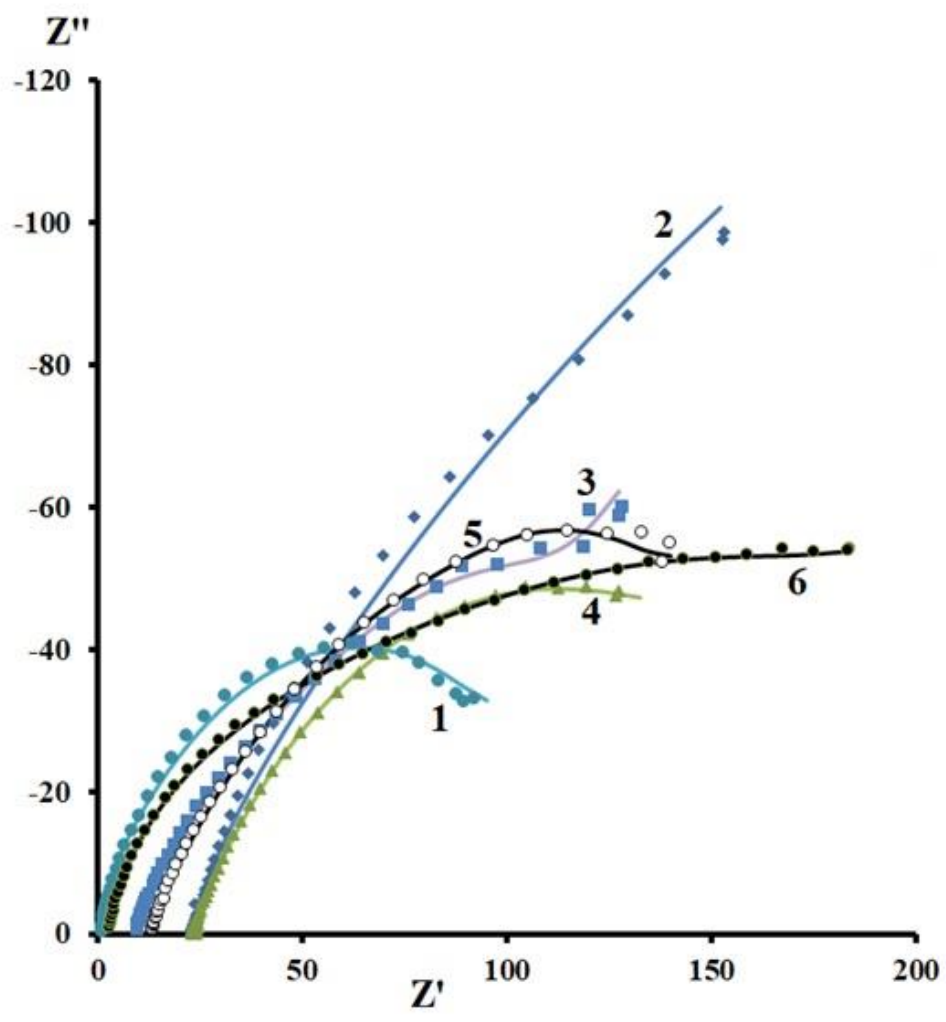

Figure 4. Hodographs of a steel electrode at the corrosion potential in a solution of $0.1 \mathrm{M} \mathrm{NaCl}$ with additives, mg/L: $1-0 ; 2-100$ IFKHAN-114; $3-10\left(\mathrm{NH}_{4}\right)_{2} \mathrm{CO}_{3} ; 4-10$ $\left(\mathrm{NH}_{4}\right)_{2} \mathrm{CO}_{3}+100$ IFKHAN-114; $5-100\left(\mathrm{NH}_{4}\right)_{2} \mathrm{CO}_{3} ; 6-100\left(\mathrm{NH}_{4}\right)_{2} \mathrm{CO}_{3}+100$ IFKHAN-114.

Hodographs are incomplete distorted semicircles resulting from a combination of two or more arcs. The hodograph corresponding to a solution of $0.1 \mathrm{M} \mathrm{NaCl}+10 \mathrm{mg} / \mathrm{L}$ $\left(\mathrm{NH}_{4}\right)_{2} \mathrm{CO}_{3}$ is characterized by a larger diameter than the hodograph measured in a $\mathrm{NaCl}$ solution that does not contain an addition of ammonium carbonate (Figure 4, curves 1 and 3). This corresponds to an increase in the total resistance in the system with the addition of ammonium carbonate and, consequently, a decrease in the corrosion rate. 
An increase in the concentration of $\left(\mathrm{NH}_{4}\right)_{2} \mathrm{CO}_{3}$ to $100 \mathrm{mg} / \mathrm{L}$ practically does not change the picture (Figure 4, curves 3 and 5). Thus, $\left(\mathrm{NH}_{4}\right)_{2} \mathrm{CO}_{3}$ acts as a corrosion inhibitor. The introduction of $100 \mathrm{mg} / \mathrm{L}$ IFKHAN-114 along with $10 \mathrm{mg} / \mathrm{L}\left(\mathrm{NH}_{4}\right)_{2} \mathrm{CO}_{3}$ leads to a decrease in the diameter of the semicircle and, consequently, to an increase in the corrosion rate (Figure 4, curves 3 and 4). Thus, IFKHAN-114 behaves as a corrosion stimulant in the presence of $10 \mathrm{mg} / \mathrm{L}\left(\mathrm{NH}_{4}\right)_{2} \mathrm{CO}_{3}$. However, in the presence of $100 \mathrm{mg} / \mathrm{L}\left(\mathrm{NH}_{4}\right)_{2} \mathrm{CO}_{3}$, IFKHAN-114 already exhibits inhibitory properties. With an increase in the duration of the experiment up to 24 hours, its inhibitory effect increases.

The results of impedance measurements are consistent with data of polarization studies.

A comparison of the data characterizing the effect of the inhibitor obtained from the electrochemical measurements with the corresponding values calculated on the basis of the results of weight tests showed a noticeable discrepancy between them, although the former confirm the presence of the inhibitory ability of IFKHAN-114 in a chloride neutral solution. The method of polarization measurements should be considered as an express method for a qualitative assessment of the inhibitory ability of corrosion inhibitors.

\section{Conclusions}

1. In the presence of chloride ions, the products of the interaction of ammonia with $\mathrm{CO}_{2}$ or $\mathrm{H}_{2} \mathrm{~S}$ formed on carbon steel in a surface phase film of moisture act as effective corrosion inhibitors. Their protective effectiveness after one-day exposure to the medium reaches $90 \%$ (hydrolysis of $\left.\left(\mathrm{NH}_{4}\right)_{2} \mathrm{CO}_{3}\right)-96 \%$ (hydrolysis products of $\left(\mathrm{NH}_{4}\right)_{2} \mathrm{~S}$ ).

2. In the presence of $\mathrm{NH}_{3}$ and $\mathrm{CO}_{2}$ in the surface film, the protective effect of IFKHAN-114 (100 mg/L) increases with an increase in the concentration of hydrolyzed salt in it, reaching $67 \%$ after 24 hours.

3. In the presence of $\mathrm{NH}_{3}$ and $\mathrm{H}_{2} \mathrm{~S}$ in the moisture film, on the contrary, the greatest protective effect of the inhibitor $(100 \mathrm{mg} / \mathrm{L})$ is observed in the region of low salt concentrations, when it is $96 \%$ after day exposure of steel in the corrosive medium.

4. The results of impedance measurements are consistent with data of polarization studies.

\section{Acknowledgment}

This work was supported by the Russian Science Foundation, grant No. 18-16-00006.

The experimental results were obtained using the equipment of the Center for Collective Use of Scientific Equipment of TSU named after G.R. Derzhavin.

\section{References}

1. V.N. Kuz'min, V.F. Fedorenko and S.N. Sazonov, Spravochnik fermera (Farmer's Handbook), Moscow, Rosinformagrotekh, 2013, 616 pp. (in Russian).

2. I.L. Rosenfeld and V.P. Persiantseva, Ingibitory atmosphernoi korrozii (Atmospheric corrosion inhibitors), Moscow, Nauka, 1985, 267 (in Russian). 
3. E.N. Kablov, O.V. Startsev and I.M. Medvedev, Corrosiveness of coastal atmosphere. Part 1, Korroz.: mater., zashch. (Corrosion: materials, protection), 2013, no. 12, 6-18 (in Russian).

4. A.A. Mikhailov, Yu.M. Panchenko and Yu.I. Kuznetsov, Atmosphernaya korroziya I zaschita metallov (Atmospheric corrosion and metal protection), Tambov: R.V. Pershin Publishing House, 2016, 555 (in Russian).

5. V.I. Vigdorovich, L.G. Knyazeva, A.N. Zazulya, E.G. Kuznetsova, N.N. Andreev, A.A. Uryadnikov and A.V. Dorokhov, Rossiiskaya sel'skokhozyaistvennaya nauka (Russian Agricultural Science), 2016, no. 1, 65-68 (in Russian).

6. V.I. Vigdorovich, N.V. Shel, L.E. Tsygankova and P.N. Bernatsky, Int. J. Corros. Scale Inhib., 2015, 4, no. 3, 210-220. doi: 10.17675/2305-6894-2015-4-3-210-220

7. V.I. Vigdorovich, L.E. Tsygankova, N.V. Schel, E.Yu. Shel, L.G. Knyazeva, A.V. Dorokhov, A.A. Uryadnikov, Zavodskaya laboratoriya. Diagnostika materialov (Factory laboratory. Diagnostics of materials), 2018, 83, no. 7, 42-46 (in Russian). doi: $\underline{10.26896 / 1028-6861-2018-84-7-42-46}$ 